\title{
Patents and licensing in pharmaceutical industry
}

\author{
Katerina Ancevska Netkovska*, Jasmina Tonic Ribarska, Aleksandra Grozdanova, \\ Zoran Sterjev
}

Faculty of Pharmacy, University "Ss. Cyril and Methodius", Majka Tereza 47, 1000 Skopje, Republic of Macedonia

Received: March 2015; Accepted: May 2015

\begin{abstract}
Intellectual property rights (IPR) have been defined as ideas, inventions, and creative expressions based on which there is a public willingness to bestow the status of property. IPR provide certain exclusive rights to the inventors or creators of that property, in order to enable them to reap commercial benefits from their creative efforts or reputation. There are several types of intellectual property protection like patent, copyright, trademark, etc. Patent is recognition for an invention, which satisfies the criteria of global novelty, non-obviousness, and industrial application. IPR is prerequisite for better identification, planning, commercialization, rendering, and thereby protection of invention or creativity. Each industry should evolve its own IPR policies, management style, strategies, and so on depending on its area of specialty. Pharmaceutical industry currently has an evolving IPR strategy requiring a better focus and approach in the coming era. The protection of inventions with patents in the pharmaceutical industry have a specific role in the development of society and represent one of the drivers of economic development. The license agreements are considered as one of the most common types of transfer of industrial property rights. The right holders often transfer their rights to patents by concluding licensing agreement. While the patent license may give the license a right to use the technology many license agreements have provisions for the transfer of know-how in addition to the patent.
\end{abstract}

Keywords: license, transfer of rights, regulation, pharmaceutical industry

\section{Background}

Intellectual property is defined as a form of knowledge protected by specific proprietary rights, resembling ownership rights over material goods. Intellectual property state awards to individuals or organizations created intellectual creations: inventions, literary and artistic works, symbols, names, images and designs. The holder of intellectual property rights has exclusivity regarding the use of protected intellectual works within a specified period of time. After the expiration of that period, it becomes the subject of free use by all individuals and organizations in society, public domain. Intellectual property as a concept covers

\footnotetext{
* Tel.: +38923 126032; fax: +38923120220

e-mail address: kaan@ff.ukim.edu.mk
}

only a part of the knowledge accumulated in people, institutions and technologies within a society. With all the faster development of science and technology, especially in the area of biotechnology, medicine, information and communication technologies, knowledge becomes a greater source of competitive advantage for national economies. Trade in high-tech goods and intellectual services, where the protection of intellectual property rights is the greatest, is one of the sectors that developed fastest in the international trade. Intellectual property rights are based on the idea of balance between private and public interests. Timelimited, these rights protect private interests (by rewarding innovators and creators), but also the public interest (through promotion and dissemination of ideas, creative works and other works of the human mind). If the intellectual property system in a country is properly positioned 
and aligned with the specifics of its political, legal, cultural and overall social system, such a system could be used as a very successful tool for economic development (In the system of the United Nations Convention on no dichotomous classification "developed / developing countries." Grouping or labeling of certain countries or regions as "developed" or "developing" more details see: http://unstats. un.org/unsd/methods/m49/m49regin.htm\#ftnc. Macedonia is registered as one of the transition countries of Southeast Europe).

International technology transfer refers to the process by which a company from one country gets access to certain technology is initially developed in another country (Source: http:/www.wipo.int/pressroom/en/articles/2009/ article_0002.html.) and it starts successfully use it. Technology transfer can take place between partners who spontaneously enter into voluntary transactions, but can also take place through non-market transactions or etc. "Spillovers" (Fink and Maskus, 2005). The impact of the high level of protection of intellectual property rights on technology transfer is ambiguous in terms of theory and depends on circumstances that exist in a given country - recipient of technology. On the one hand, stronger intellectual property protection can limit the spread of technology, with the presence of patents that prevent unauthorized use of commercially valuable knowledge, as well as increased market power of the holders of intellectual property rights. It can also lead to potentially reduce the dissemination of knowledge, because of the relatively lower and higher production rates. On the other hand, relatively the stronger intellectual property rights can play a positive role in the dissemination of knowledge, given the detailed information about the technologies described in patent applications, made available to other potential inventors. In addition, the strong protection of intellectual property rights can stimulate technology transfer through increased trade in goods and services, foreign investment, technology licensing, and increased joint ventures. Despite the existence of theoretical ambiguity, the spread of technology from technologically developed countries to less developed are considered the main benefit of TRIPS. Benefits would be particularly important for developing countries that have no marked capacity for innovation. It is empirically proven that increased protection of intellectual property can encourage transfer of technology in various ways, though the final resultant effect is dependent on various factors including the ability of the country to support the legitimate imitations, and the level of technological development (World Bank 2008).

\section{Intellectual property rights}

The consequences of the high level of protection of intellectual property rights depend, among other things, the level of development of the country (expressed by gross domestic product per capita, or human capital). For most countries with relatively higher incomes, strengthening of intellectual property drives economic growth at least in part, due to increased innovation and increased dissemination of technology. Protection of intellectual property in these countries already meet or exceed the TRIPS standards, leaving the countries possibly strengthening the regime of their intellectual property rights (Fink and Maskus, 2005; World Bank, 2008).

Intellectual property should be seen as an instrument for achieving certain goals, which over time evolved and are specific to a period and a country. For example, in the US, the weak protection of copyright in the XIX century plan was aimed at encouraging the development of the domestic publishing industry. Similarly, in the history of the development of intellectual property systems in continental Europe, where the development of certain industries gradually grew and standards of protection of intellectual property (eg. in the pharmaceutical industry) or certain countries were forced to strengthen the system of industrial property by signing free trade agreements, eg. Spain and Portugal (Carlos Correa, Formulating effective pro-development national intellectual property policies, University of Buenos Aires ICTSD-UNCTAD Dialogue, Bellagio, 30 Oct.-2 Nov. 02.)

The formulation and implementation of appropriate national strategy in the field of intellectual property is a challenge for developing countries, particularly intellectual property should be put in function of economic development. There are several reasons why this task is challenging. The field of intellectual property is complex and includes multiple segments that have different roles (Patent, trademark, industrial design, copyright and related rights, etc.). Because of this, any generalization about the impact of the intellectual property system for the economic development of a country would have very little practical significance. Patents in the field of pharmaceutical products can lead to loss of static efficiency by disabling access to cheap medicines to the citizens of the country in development. On the other hand, brands can lead to increased levels of consumer protection through the designation of high quality products.

\section{Inovation and $R \& D$ in pharmaceutical sector}

The strict system of protection of intellectual property may have a different impact on different groups (eg, consumers and manufacturers) even within a single sector of the national economy. For example, a pharmaceutical company that invests significant resources in R \& D would be a potential advocate for the introduction of strict protection of industrial property rights in order to protect their inventions in which incorporated much like the material and the intellectual aspects. On the other hand, consumers would like to have access to a range of cheaper, generic drugs. Also, the introduction of strict system of protection of copyright and related rights in favor of musicians, art- 
ists, but this system can generate restrictive approach to the works of these artists by the poorest population.

The pharmaceutical sector is complex and highly regulated in most economies. Government price controls and purchasing, public and private insurance schemes, restrictions on marketing and promotion, and the involvement of "learned intermediaries" such as physicians and pharmacists powerfully influence demand for pharmaceuticals. On the supply side, stringent product safety review, regulatory oversight of manufacturing, and legal frameworks governing technology transfer between publicly-funded research institutions and commercial entities play an equally significant role in shaping competition. Importantly, since much of the research on pharmaceuticals has been focused on questions specific to the market institutions and regulatory framework of high-income economies such as the US and the EU, the extent to which this literature provides a firm foundation for evaluating the impact on policy changes in developing countries and countries with economies in transition is therefore unclear.

IPRs are generally understood to have two principal areas of impact in pharmaceuticals. First, there is the issue of pricing and access, where discussion focuses on the links between IPRs (particularly patent rights), exclusion of competitors and the availability and pricing of new medicines. Second, there is the issue of R\&D incentives - that is to say, the role of IPRs in providing incentives to discover, develop and market new drugs - and the effect of IPRs on R\&D expenditure and its allocation across diseases, countries and organizations. Obviously, these two issues are closely linked, and their interplay presents a series of very difficult economic issues and policy questions.

Even in a single-country context, the use of IPRs to reach an appropriate balance between "static" gains to consumers from low prices and competitive supply of drugs with "dynamic" gains from innovative new products presents serious challenges. On the one hand, industry feels acute financial pressure from rising R\&D costs and decreasing effective patent life. On the other, notwithstanding very substantial economic and health benefits associated with innovation in pharmaceuticals, even in relatively wealthy countries high prices for on-patent drugs tend to raise difficult political questions relating to equity and access for low-income or disadvantaged groups, and for setting priorities in allocating public health care budgets.

Looking cross-nationally, differences among countries in their approaches to these fundamental policy issues present additional challenges. The supply side of the industry operates globally. Industry R\&D is conducted largely by multinational companies who operate R\&D facilities in multiple countries, relying on and contributing to a transnational science base, and products are sourced and manufactured globally and are sold in essentially identical form in many different countries. Yet on the demand side, markets are essentially national, with significant hetero- geneity across countries in IPR regimes and health care insti- tutions.

The complexity of these issues demands careful empirical analysis. Yet, there are some very serious gaps in our knowledge, particularly as regards development of data that would support informative research into the impact of IPRs in this sector. Licensing as a channel of technology transfer can occur as a substitute for foreign direct investment. The level of protection of intellectual property rights may affect the selection of a company between licensing and foreign direct investment (Horstmann and Markusen, 1987). The high degree of protection of intellectual property contributes to favoring licensing by a firm technology provider because there is a legal framework that offers an opportunity for easy execution of licensing agreements. On the other hand, lack, ie low level of protection of intellectual property rights, and patents in particular, creates problems in the implementation of the licensing agreements (Markusen, 1995). In this case, the recipient of technology can quickly discern the technological procedure and imitated by creating a new local company that would emerge as a competitor to the provider of the technology. (Markusen and Maskus, 2001). From this perspective, the strong patent protection encourages increased conclusion of license agreements, since the patents act as inhibitors of potential risks in licensing of intellectual property.

Studies conducted on American multinationals have shown that the likelihood of licensing markets in developing countries is inversely proportional to the level of protection of intellectual property rights (Antras et al., 2006).

Therefore, this paper aims to give a brief overview of the segment of intellectual property in an area which is increasingly gaining in its importance. It is about the effects that provide patents on pharmaceutical companies and the importance of licensing in this business sector.

\section{Patents}

A patent is an exclusive right granted in the procedure by the Law (Law on industrial property „Official Gazzete of Republic of Macedonia” no. 21/2009, 24/2011, 12/2014, $41 / 2014,152 / 2015$ ), on inventions in all fields of technology which is new, it contains inventive contribution and can be applied in industry.

The patent is the right to intellectual property, which appears as the most widespread form, which has based inventor of the protected invention, and is an important factor for economic development and general progress (Cornish, 1993). The finding comes as the final result of the previous work, which is materialized the product of an individual or group of people, why legal protection enjoyed only one inventive work that gives certain results.

The patent as subjective right belongs to legal person, to a territory and for a certain time, and the holder of the patent rights have an exclusive right protected invention to use and exploit the material and moral values for the duration of patent protection. 
To protect as a patent need to build effective system that not only rewards the investment of time, money and effort it will provide and its adequate protection, which will stimulate innovation with new investments in research and development.

Patent may be for protection of a product, process or material. As necessary criteria that cumulatively fulfill the invention to be patentable: novelty, inventive step and applicability in industry (Polenak-Akimovska et al., 2004).

However, although the invention is patentable, it is always wise to apply for protection. A patent may be expensive, difficult to obtain, maintain and enforce, not to give the expected gain. Above all, it is necessary to do the analysis. The analysis should include the following elements: the existence of a market for the invention, the existence of an alternative and comparing whether and how useful for improving an existing product or developing a new product, having potencijlni buyers of the license, if the expected profit market will justify the costs of patenting, which aspects of the invention can be protected by one or more patents, will be easy to identify violation of the patent rights and finally, how the company will be able to apply patent.

Therefore, the patent serves as a powerful business tool to get a monopoly on a new product or process that is associated with the advancement of innovative companies in terms of dynamic business climate. The reasons for the findings pateniranje undeniable is their role to: competitive advantage in the market ${ }^{1}$, the higher the profit or return on investment, additional revenue from licensing or transfer of the patent, access to other technologies through cross-licensing, sale of new markets through licensing of patents reduced risk of damage to the patented invention, increased the possibility of obtaining grants, taking action against falsiifikuvanje positive view of the patent portfolio to business partners, investors, shareholders, customers and others ${ }^{2}$.

Statistically, companies that use intellectual property rights are more successful than those who do not use them ${ }^{3}$.

The surveyed companies said they use or plan to use one or more types of rights and the rank of those who are subject to registration as well as those that are not, including utility models $(16 \%)$, protected design (19\%), tech-

\footnotetext{
A patent gives the owner the exclusive right to prevent or stop others from commercially using the patented invention

2 We can treat it as a demonstration of the high level of expertise, specialization and technological capacity

3 Example: European companies in the sector of technology use intellectual property rights registered at least $10 \%$ a higher turnover, market share and new jobs. According to the International Data Corporation for the European Commission in 2008 in the sector of information and communication technology in eight EU Member States (Austria, Germany, Spain, France, Ireland, Italy, Poland and the UK), $89 \%$ of companies stated that PSI use one or more intellectual property rights, and $74 \%$ said that these rights important to them, while $34 \%$ rated them for,,very important,,.
}

nical measures protection $(27 \%)$, patents $(32 \%)$, brand $(40 \%)$, copyright $(46 \%)$ and trade secret $(72 \%)^{4}$.

In patent law distinguishes between the rights of the inventor and the right to the patent holder, since they do not have to belong to the same person.

If not also the inventor and patent holder enjoys the moral right to be appointed in the application and the documents concerning the patent. The holder of the patent, on the other hand have exclusive rights to the protected invention. According to its legal nature of this right is absolute character and the entry in the register has the effect erga omnes.

In the wider meaning the patent can be understood as a legal relationship that derive certain legal obligations as holder of the patent, and for all others. In narrower meaning, patent equals the subjective right arising from these legal relationships. According to the majority of legal theorists, the content of the subjective right arising from the patent as a legal relationship, the holder of a patent is a civil legal authority of title character (Polenak-Akimovska et al., 2004).

The content of the subjective right constitute rights are entitled exclusive rights (Law on industrial property „Official Gazzete of Republic of Macedonia”, no. 21/2009, 24/2011, 12/2014, 41/2014, 152/2015): the right to use, right to use the right to compensation and the right to prohibit third parties from unauthorized use ${ }^{5}$. Given its exclusive (absolute) legal nature, the holder of a patent confers the powers under certain authors may be characterized as positive and negative powers. The positive powers related to the ability to: 1 . use the protected invention in production, 2. to put into circulation objects made according to the protected invention, and 3 . dispose of the patent.

If the patent was obtained for the procedure, its effect extends to the products and materials obtained directly by that process (Law on industrial property „Official Gazzete of Republic of Macedonia”, no. 21/2009, 24/2011, 12/2014, 41/2014, 152/2015).

The negative aspect of the content of the patent covers the holder the right to prohibit use of the protected in-

\footnotetext{
4 International Data Corporation 2008: Intellectual property rights to use not only to protect their inventions and the market, but to attract investment, licensing and cross-licensing as well blocking competition. Also, at least 10\% more of the useful that these rights have reported growth for a period of 12 months and $61 \%$ higher turnover, $49 \%$ higher $42 \%$ market share and employment, as opposed to those who do not use them.

5 The content of the subjective right to the patent cost exclusive rights (legal property, positive powers) the patent holder to manufacture and circulates objects made according to the protected invention. This right is exclusive, monopolistic character, because only the patent holder and the persons who have his permission have the right to use, produce and put into circulation objects made according to the protected invention. Among these rights is no conditionality, because the exceptional right of putting items on the market is conditioned by the use in production.
} 
vention in production or sale of third parties', who use it do not have a license and refers to the manufacture, sale, export or import and storage products for such purposes (Law on industrial property „Official Gazzete of Republic of Macedonia", no. 21/2009, 24/2011, 12/2014, 41/2014, $152 / 2015)$.The patent holder has the right to prohibit third parties who do not have permission to use the protected invention in production or turnover. This right, which is a negative power is complementary to the positive powers by a right of personal use, with the right of possession to their qualification as exclusive rights.

In any case, it must be emphasized that the scope of the exclusive rights of the patent holder is determined by the text of the claims which are finally accepted in the patent granting procedure, where the description and drawings serve to interpret the claims (Law on industrial property „Official Gazzete of Republic of Macedonia”, no. 21/2009, 24/2011, 12/2014, 41/2014, 152/2015). There are situations when the right holder is limited, that there are exceptions to infringement of the patent, eg. Biotechnology (Law on industrial property „Official Gazzete of Republic of Macedonia", no. 21/2009, 24/2011, 12/2014, 41/2014, 152/2015).

It can be concluded that it is a monopoly right which contained more powers or rights holder of a patent. This character and the importance given to these rights, not only to meet the economic needs of the country but also to stimulate innovation and creativity (Polenak-Akimovska et al., 2004). Subjective rights arising from patent spatial, temporal and really limited. The territorial limitations apply that patent recognized by a state institution applies to the territory of that country. It should be noted that even in cases where the procedure for grant of patent is guided by an inter-state institution that has ovlastenje from several countries, after recognition of the patent applied teritoritorijalniot principle of importance, that subject to the provisions of national legislation. The territorial principle of protection is of particular importance in violation of the patent. Protection from harm is only possible in the country where the patent is valid or can not initiate dispute infringe the patent in a country where no registration. The timeframe of a patent is determined by the limited validity. The real limitation of the right is seen that the patent rights applies only to the object of the invention is protected by patent, and not to any other object.

Also, enumerates cases when the use of the invention protected by the patent does not constitute an infringement of a patent, or if the invention can be freely used (Law on industrial property ,Official Gazzete of Republic of Macedonia", no. 21/2009, 24/2011, 12/2014, 41/2014, $152 / 2015)$. The reasons that limit the effect of the patent in certain cases the use of social and social nature, in terms of meaning and purpose of patent protection. They relate to the use which is of such a scale and nature that causes extensive damage to the right holder, and use for scientific and research purposes. Here take into account the public interest. The exploitation of the protected invention in personal and non-commercial purposes (cumulative) is not a form of application which may endanger the use of the invention in the production and circulation of products according to the invention ${ }^{6}$. Activities undertaken research and development of the subject of the protected invention also allowed as free use of the patent. One of the primary purposes of patent protection is to encourage technological development, therefore it is logical to expect that patent protection should not be an obstacle for investigations that lead to further development in the field of the invention. This is especially important on how to use the case when the activities related to examinations and tests required for registration of medicines for human and veterinary medicine, medical and veterinary products or products for plant protection. Here it is cited in particular the case when it comes to inventions in these areas that require lengthy investigations and trials prior to commissioning, as is the case with pharmaceutical products (Polenak-Akimovska et al., 2004). Also, in case when referring to direct and individual preparation of medicines in pharmacies single doctors prescription. The provision refers to the procedure for preparation of the drug, if it is a protected procedure. The basis of this provision is in the general ethical and health interest, according to which a patent right should not be an obstacle to the preparation of the drug in individual cases. It is clear that the free use is possible only in case of individual preparation, not for production which will provide feedstock use, even in cases where production is realized in the pharmacy, which means that exempts production of medicines in galenic laboratories where they are intended for general application, not produced as individual products on the basis of a single prescription.

\section{The role of licencing patents in pharmaceutical indistry}

Licensing is considered one of the most important sources of international technology transfer to developing countries. It usually covers the purchase of rights to produce innovative goods or services, and / or rights to their distribution, and sale of basic technical information and know-how incorporated in the corresponding good, ie service. Licensing involves transfer of intellectual property which is affiliated with the innovative product, ie service, which appear as the subject of the license agreement (Yang and Maskus, 2003).

The relationship between licensing, technology dif-

\footnotetext{
This provision has the greatest practical significance for imported product for which there is a patent protection in the country of import. In this case, if the import is carried out for personal and non-commercial purposes, this action does not constitute a violation of the patent. Otherwise violate the law if imported products are intended for commercial purposes and for use by others.
} 
fusion and the level of protection of intellectual property is relatively complex and multifaceted than in other channels of technology transfer. One of the most important reasons according to Maskus (Maskus, 2003) lies in the diversity of the license agreements. License agreements can be concluded within the same group of companies within the joint venture, as well as between completely unrelated firms. These agreements may cover a wide range of areas, such as the subject of such contracts may be technical assistance, transfer of codified knowledge, transfer of knowledge and skills and transfer of intellectual property rights.

Today each country that seeks and highly prosperous economy, its development strategy through channel increasing degree of implementation mechanisms provided for the exercise of rights to protection of industrial property. The protection of inventions with patents in the pharmaceutical industry have a specific role in the development of society and represent one of the drivers of economic development. The costs that occur during the creation of new chemical supsatncii suspatnici as active in order for treatment is associated with building a reliable and efficient system in the research process. The length and duration of the research stages is difficult to predict because of many unpredictable moments. Therefore, it is common to take several years between baseline and registration of the first patent. The first patent application to register quite early, generally after the first detection of a successful operation, To ensure strict patent rights, and it would protect the third party. The purpose of patents is to create exceptions, but companies are not used to. The patent s right holder has the right to dispose of the patent. According to some scholars, the existence of positive powers is justified precisely by the right of disposal, especially the right of derogation the use of the patent by giving license.

The value of the patent or its licensing may differ greatly and may be difficult to determine the monetary value. Usually, it is compensation for the use of up to $5 \%$ of gross sales or $25 \%$ of net sales for those products include licensed invention. The license can also include advance payments in addition to the annual fee for use. There are companies that help the licensing of patents, and in return receive a share of the fee for licensing. Sometimes the amount of that portion can be one third of the benefits received by the license. If patents are available in technological areas that no one is interested, licensing may be a good alternative to doing nothing, ie to apply for a new patent ${ }^{7}$. Today, unless you pay fees to maintain the patent in force, the patent protection expires and technology over

For example, in Britain commenced granting licenses for drugs forced on the occasion of the introduction of public health protection. Ministry of Health of this country there was a need for large amounts of drugs, among them especially antibiotics. At that time antibiotics were modern drugs and patents for their production had big American corporations that put them on the market with higher prices. which it has rights over publicly available. Someone could be tempted to leave the patents developed technology that is commercialized or critical to the business. Perhaps with the help of external associates, lawyers or similar consulting firms can prepare a list of potential licensees, which will use the proper discretion of the pharmaceutical companies. If successful in licensing this patent unproductive capital can be turned into productive.

As a novelty in the Industrial Property Law in Macedonia which was introduced as a result of harmonization of national legislation with the Declaration which concerned the relationship of the TRIPS agreement, public health, pharmacy and complusory license taken within Doha Declaration, ratification of the European Patent Convention and issuance of the compulsory license. Before legislator refers to the release of complusory license so that if the patent holder does not use the invention protected by the patent or uses the extent insufficient to meet the needs of the domestic market, while refusing to enter into a license agreement or non-market sets conditions with a compulsory license the right to use the invention can be given to another person with responsibility for paying compensation to the holder of patent. These compulsory licenses may be issued to protect the public interest and in the health is particularly important for aspect of this work. In addition, we want to emphasize that the procedure for issuing a compulsory license shall be initiated by a lawsuit against the holder of the patent or supplementary protection certificate, which contains a requirement to issue a compulsory license. For the purposes of public health court, in accordance with Law to any person who has submitted a request to issue a compulsory license for a patent of supplementary protection or for the needs of production and sales of pharmaceutical products, if such products intended for export to importing countries problems in public health. In addition, the legislator defines country can be treated as an importing country or as a country that exported pharmaceutical products. The compulsory license can not be exclusive. The duration and scope of its issuance depend solely on the duration of the cause for which it was issued. The compulsory license may be transferred only together with the production capacity, ie the part in which the invention is used for validity. Also kolchinata products that can be produced on the basis of the compulsory license shall not exceed the amount needs to meet the importing country.

According to the Article 102, by Law on industrial property in Macedonia, any person that has filed an application in compliance with the provisions of this Law may be issued, by the court, a compulsory patent license i.e. a supplementary protection certificate for the needs of production and sale of pharmaceutical products, where such a product is intended to be exported in the importing countries with problems in public health. Also, when deciding upon issuing compulsory license, the court shall take into consideration the WTO General Council Decision of 30 August 2003 on the implementation of para- 
graph 6 of the Doha Declaration on the TRIPS Agreement and public health of 14 November 2001 (hereinafter referred to as: "Decision"). The pharmaceutical product referred to in paragraph (1) of this Article shall be any product in the pharmaceutical industry, including the medications for human use, which include any substance or mixture of substances designed for treatment or prevention of human diseases including any substance or mixture of substances which may be applied to people in terms of renewal, improvement, or adjustment to their physiological functions by causing pharmaceutical, immunological, or metabolic effects or by giving the medical diagnosis, including active components and accessories to diagnose outside the alive human body.

Because having a diametrically opposite social goals often comes to creating fiction between legal norms regulating unfair competition ( Law on Protection of Competition, Official Gazette no. 145 of 05.11.2010; Law against Unfair Competition, Official Gazette no. 80/99 of 17/12/1999) and intellectual property (Law on industrial property „Official Gazzete of Republic of Macedonia”, no. $21 / 2009,24 / 2011,12 / 2014,41 / 2014,152 / 2015)$. On the one hand, intellectual property rights creates exclusive and entry barriers to the market, in order to allow the company - holder of intellectual property the extra profit that would serve as an incentive to invest in the further creation of innovation. Ideally, such a balance provides consumers better products in the future, at the expense of somewhat higher current expenses. By contrast, legislation in the field of unfair competition, strives to enable consumers in a given moment to get the product at the lowest possible cost. In simple words, intellectual property law creates legal fictions in the form of monopoly and the right which regulates unfair competition contains express prohibitions on the formation of monopolies. The point of equilibrium between these two types of legislation will depend in part from the discount rate (cost of money) and balance present versus future; hence, the degree of balance between these two types of law will vary between relatively affluent and relatively poorer countries. For example, in the second half of last century until the seventies, in the legal system of the US balance was shifted strongly in favor of regulation of unfair competition, expelling it the intellectual property right (Barton, 2007).

Changes in the economic analysis also led to changes in legislation of developing countries which regulates the matter of unfair competition and intellectual property. Hence, the key issues emerged in the treatment of global oligopolies that could restrict access of developing countries to global competition and affect multinational acquisitions of local firms. From the perspective of developing countries that have a desire to acquire high technology, the most important international antitrust issues arising from the fact that much of the high technology to create so-called monopolies or oligopolies in a relatively small number of companies that may be willing to cross-license their technologies to one another, but are less willing to license their technology to potential new members of the oligopoly, and above all the companies coming from developing countries. As an example we can take the model of development of the sector of computer operating systems, the semiconductor sector and the sector of agricultural biotechnology (World Bank, 2008; Barton, 2007).

Concentration of industry in a monopoly or oligopoly may lead to unwanted cuts in investment in R \& D. Under such circumstances, some activities of leading firms could be antitrust violations. Antitrust argument is strongest if it leads to a company trying to gain market power beyond the scope of its acquired intellectual property, or if the company agrees to license its technology to the existing powerful competitors, but refuses to do so in a new competitor (for example, a company that comes from a developing country). When there are valid arguments for the protection of intellectual property, an appropriate solution to break the ensuing monopoly can be provided through the implementation of a compulsory license. Such circumstances are rare, and the applied standards are the subject of constant debate. However TRIPS allows such compulsory licenses within a reasonable range of anti-competitive situations (Fink and Maskus, 2005).

Another important antitrust issues for developing countries is the mode in which multinational companies will enable them to undertake local firms. Such acquisitions can be a normal step in the global movement of industries to large scale operations. In addition, downloads can bring new technology from abroad. This is the case particularly in the sectors of telecommunications and agricultural biotechnology. However, such acquisitions may affect the reduction of competition in developing countries. Balancing these two opposing effects requires a wise state antitrust body with considerable economic power (Fink and Maskus, 2005).

Another important antitrust issues for developing countries is the mode in which multinational companies will enable them to undertake local firms. Such acquisitions can be a normal step in the global movement of industries to large scale operations. In addition, downloads can bring new technology from abroad. This is the case particularly in the sectors of telecommunications and agricultural biotechnology. However, such acquisitions may affect the reduction of competition in developing countries. Balancing these two opposing effects requires a wise state antitrust body with considerable economic power (Fink and Maskus, 2005).

\section{Conclusion}

The protection of intellectual proerty right can be of a great importance for the development of a society, it can contribute to strengthening of economy and improve life standard. International community has established standards for protection of intellectual property rights through relevant international documents and thus gave guidelines 
on the improveent of thoir protection internationally. The states who are the leaders in innovation and creativity establish strong legal mechanisms which providethe protection of intellectual property rights. It is generally accepted that only legal use of intellectual property can bring innovation and progress to a society. There is a tendency in the international circles to support the flow of information and the freedom of expression through media especially now in the era of Internet. It is believed that it is necessary for all the sectors to cooperate with the state in order to find practical and efficient solutions for the protection of intellectual property rights. Types of intellectual property infigement are usually manifested through illegal production, smugglng and distribution of counterfeit products, including pharmaceuticals.

Considering the fact that the subject of protection are intellectual acts, we could conclude that patent legal rules achived high level of harmonization and unification. The tuning process followed by World Organization for Intellectual Property is synchronized with the same process on EU level. The global caracter of pharmaceutical company business asked for global rules in paten protecion of pharmaceutical products. The patent protection of pharmaceutical products is fundamentally to the pharmaceutical industry, which consists of two sectors: the innovative sector and generic sector. As far as the patents are concerned, recent academic works focus on several issues of impotrtance of patents: the actual impact of strong patents on innovation, commercialization, and economic growth, institutional factors, ranging from the structure of research organizations to seemingly tangential recommendation for future activities in using patents encompass data collection of R\&D output by the government agencies, research on patent policy implementation and policy changes (Hahn, 2003). The innovative sector is entirely dependet on patents and on a strong and effective patent protection system (20-year product patents protection can now be increased by up to more year through a Supplementary Protection Certificate). So, is thrue when the analyzing of intellectual property rights through the scope of economics in an outcome of concept of intellectual property is closely affiliated with innovation, technology and development. In the XXI century, intellectual property is no longer seen as an antonomous and separate area and has become a significant tool for policy making with socio-economic, technological and cultural repercussions (Mr. Kamil Idris, the Director General of WIPO 2007).

\section{References}

Antras, P., Garicano, L., Rossi-Hansberg, E., 2006. Offshoring in a Knowledge Economy. The Quarterly Journal of Economics, 121 (1), 31-77.

Barton, J.H., 2007. New trends in technology transfer: implications for national and international policy. ICTSD Programme on IPRs and Sustainable Development, Issue Paper No. 18. International Centre for Trade and Sustainable Development.

Correa, C. M., 2003. Can the TRIPS Agreement Foster Technology Transfer to Developing Countries? Duke University, manuscript.

Cornish, W.R., 1993. The International relations of intellectual property. Cambridge law journal.

Fink, C., Maskus, K.E., 2005. Intellectual Property and Development: Lessons from Recent Economic Research. World Bank Publications, Washington, DC.

Law on Protection of Competition, Official Gazette no. 145 of 05.11.2010

Law against Unfair Competition, Official Gazette no. 80/99 of $17 / 12 / 1999$

Law on industrial property „Official Gazzete of Republic of Macedonia“" no. 21/2009, 24/2011,12/2014,41/2014,152/2015

Polenak-Akimovska, M., Anastasovska Dabovik, J., Pepequgovski, V., Buckovski, V., Varga, Lj., Naumovski, G., 2004. Pravo na industriska sosptvenost, Skopje

Hahn, R.W., 2003. The Economics of patent Protection: Policy Implications from the Literature, AEI-Brookings Joint Center for Regulatory Studies, Washington, D.C.

Horstmann, I., Markusen, J. R., 1987. Licensing versus Direct Investment: A Model of Internalization by the Multinational Enterprise. Canadian Journal of Economics. 20(3), 464-481.

Markusen, J. R., 1995. The Boundaries of Multinational Enterprises and the Theory of International Trade. Journal of Economic Perspectives. 9 (2),169-189.

Markusen, J. R., Maskus, E. K., 2001. Multinational Firms: Reconciling Theory and Evidence, in: Topics in Empirical International Economics: A Festschrift in Honor of Robert E. Lipsey. National Bureau of Economic Research, Inc., pp 71-98.

Maskus, K.E., 2003. Encouraging international technology transfer. In UNCTAD/CTSD Capacity Building Project on International Property Rights and Sustainable Development, pp. 1-60.

World Bank , 2008. Global Economic Prospects: Technology Diffusion in the Developing World.

World Bank, 2011. World Development Indicators.

Yang, G., Maskus, K.E., 2003. Intellectual Property Rights, Licensing and Innovation. Policy Research Working Paper, The World Bank, No. 2973. 


\title{
Резиме
}

\section{Патенти и лиценцирање во фармацевтската индустрија}

\author{
Катерина Анчевска Нетковска*, Јасмина Тониќ Рибарска, Александра Грозданова, \\ Зоран Стерјев
}

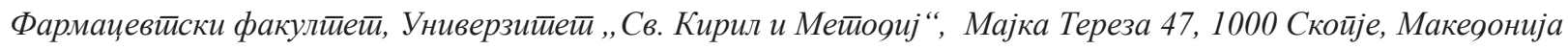

Клучни зборови: лиценца, пренос на правата, регулатива, фармацевтска индустрија

Правата на интелектуална сопственост (ПИС) се дефинирани како идеи, пронајдоци и креативни изрази кои обезбедуваат ексклузивни права на пронајдувачите или креаторите, со цел да им се овозможи користење на комерцијалните придобивки како резултат на нивниот креативен напор. Постојат неколку видови на заштита на интелектуалната сопственост, како патенти, авторски права, трговски марки и сл. Патентот е признание за пронајдок, кој ги исполнува критериумите на новост, инвентивност и индустриска применливост. ПИС е предуслов за подобра идентификација, планирање, комерцијализација, а со тоа и заштита на пронајдокот или креативност. Секоја индустрија треба да развива сопствени политики од интелектуална сопственост, управување со стил и стратегии во зависност од областа на специјалноста. Фармацевтската индустрија во моментов има стратегија на развојот на правата на интелектуална сопственост кои бараат подобар фокус и пристап во наредниот период. Заштитата на пронајдоци со патенти во фармацевтската индустрија има специфична улога во развојот на општеството и претставува еден од двигателите на економскиот развој. Лиценцните договори се сметаат за еден од најчестите типови на пренос на правата од индустриска сопственост. Носителите на правата често ги пренесуваат нивните права на патенти со склучување на договор за лиценцирање. 
